EREM 72/3

Journal of Environmental Research, Engineering and Management Vol. 72 / No. 3 / 2016 pp. 59-74 DOI 10.5755/j01.erem.72.3.14120 (c) Kaunas University of Technology
Artificial Neural Network Modelling of Biochemical Oxygen Demand and Dissolved Oxygen of Rivers: Case Study of Asa River

Received 2016/02

Accepted after revision 2016/12

\title{
Artificial Neural Network Modelling of Biochemical Oxygen Demand and Dissolved Oxygen of Rivers: Case Study of Asa River
}

\author{
Kamoru Akanni Adeniran, Bashir Adelodun, Matthew Ogunshina
}

Department of Agricultural Engineering, University of Ilorin

P.M.B. 1515, Ilorin, Kwara State, Nigeria

Corresponding author: kadeniran_2003@yahoo.com

Kamoru Akanni Adeniran, Department of Agricultural Engineering, University of Ilorin

P.M.B. 1515, llorin, Kwara State, Nigeria

Water quality assessment involves the determination of a number of parameters using several analytical methods which are often tedious and time consuming. Artificial Neural Network (ANN) was used in this study to model the relationship between fifteen (15) water quality parameters used to predict other two (2) related parameters in other to reduce the burden of long experimental procedures. Water samples were collected from six (6) point and non point sources of pollution along Asa River in llorin during the peak of rainy season (June-Aug, 2014) and peak of dry season (Nov-Jan, 2015). Physical and chemical parameters inputted into the models include pH, turbidity, total dissolved solids, temperature, electrical conductivity, dissolved oxygen, biochemical oxygen demand, chemical oxygen demand, hardness, chloride, sulphate, phosphate, calcium, magnesium and nitrate. The output models include: biochemical oxygen demand (BOD) and dissolved oxygen (DO). The three layer feed-forward model with back-propagation multi-layer perception (MLP) models architecture of 15-9-1 for BOD and 15-13-1 for DO yielded optimal results with 9 and 13 neurons in hidden layer for BOD and DO respectively. The ANN was successfully 
trained and validated with $83 \%$ and $17 \%$ of the data sets respectively. Performance of the models was evaluated by statistical criteria of average error (AE) and mean square error (MSE). The correlation coefficients of ANN models for prediction of BOD and DO were 0.9525 and 0.9556 respectively. Sensitivity analysis was also carried out to identify the most significant input-output relationship. Hence, the ANNs was able to show remarkable prediction performance to predicting the BOD and DO in Asa River, Ilorin.

Keywords: Artificial Neural Network model, Asa river and water quality parameters.

\section{Introduction}

Stream pollution is any impairment to the native water characteristics through the addition of anthropogenic contaminants to the extent that it is no more useful for drinking purposes or support the biotic communities living on it (Agrawal et al., 2010). Stream pollution is a growing problem in llorin as a result of increasing number of industries, residential buildings as well as agricultural activities that are contributing to the stream pollution. Eletta et al. (2005), Adekunle and Eniola (2008) and Ogundiran and Fawole (2014) reported that Asa River is subject to high level of eutrophication due to the organic matter and industrial effluents discharged into it. Water quality is one of the main characteristics of a river, water quality has to be simulated and predicted. If predicted quality is not satisfying, some changes or precaution measures must be implemented. To prevent this unwanted trend, control of water pollution seriously has become very essential to maintain the sustainability of water resources. Water quality can be evaluated by a number of critical parameters selected carefully to represent the pollution level of the water body of concern and reflect its overall water quality status. However, since no individual parameter can express the water quality sufficiently, the water quality is normally assessed by measuring a broad range of parameters (such as temperature; $\mathrm{pH}$; electric conductivity (EC); turbidity; and the concentrations of a variety of pollutants, including pathogens, nutrients, organics, and metals). In general, the organic pollution in an aquatic system is measured and expressed in terms of the biochemical oxygen demand (BOD) and dissolved oxygen (DO) levels. An artificial neural network (ANN) is a mathematical structure designed to mimic the information processing functions of a network of neurons in the brain (Jensen, 1994, Andy et al., 2004)). Computational modelling of hydrological processes, regardless of their structural diversity can be grouped into three broad categories; black box or system theoretical models, conceptual models and physically-based models (Karim, 2009). Black box models normally contain no physically-based input and output transfer functions. It is therefore considered to be purely empirical models. Artificial Neural Network (ANN) is one of the artificial intelligent techniques and a typical black box model (Abdulkadir et al., 2012). Relationships between dependent and independent variables have been used to relate pollution indicators and estimate the quantity and quality of pollutants or indicators in water bodies (Waziri and Ogugbuaja, 2010). The objectives of this study were to use the ANN to develop models for Asa River water pollution in Ilorin, Kwara State, to find the best neural network architecture for the process artificial model in the prediction of Asa River water pollution and to evaluate the performance of the process of ANN models after the elimination of some less significant input parameters through stepwise regression analysis.

\section{Materials and Methods}

\section{General Description of Asa River}

Asa River (Fig 1a) has its source from Oyo State, Nigeria (Fig 1b) and it flows through Ilorin, Kwara State, Nigeria in a South-North direction forming a dividing boundary between Eastern and Western Ilorin. It is about $56 \mathrm{~km}$ long, with a maximum width of about $100 \mathrm{~m}$ (at the dam site) (Ogunlela and Adelodun, 2014). Asa River has its estuary at River Awon, which is one of the tributaries of River Niger, at 12,200 m North of Ilorin. It is joined by River Oyun to the East and to the West by River Imoru. Afidikodi, Ekoro, Obe are among the earliest tributaries of Asa River while its tributaries in Ilorin include River 
Agba, Aluko, Atikeke, Mitile, Odota, Okun, and Osere. (Ibrahim et al., 2013). Asa catchment is located between latitudes $8^{0} 36^{\prime} \mathrm{N}$ and $8^{\circ} 24^{\prime} \mathrm{N}$ and longitudes $4^{\circ} 36^{\prime} \mathrm{E}$ and $4^{0} 10^{\prime} \mathrm{E}$ with total catchment of about $1037 \mathrm{~km}^{2}$ at the confluence which lies within Kwara State and Oyo State with about one third the basin area in Oyo State (Ogunlela and Adelodun, 2014).

\section{Fig. 1}

a) Map of Asa River (llorin) showing the sampling points b) Map of Nigeria showing Ilorin Cityts
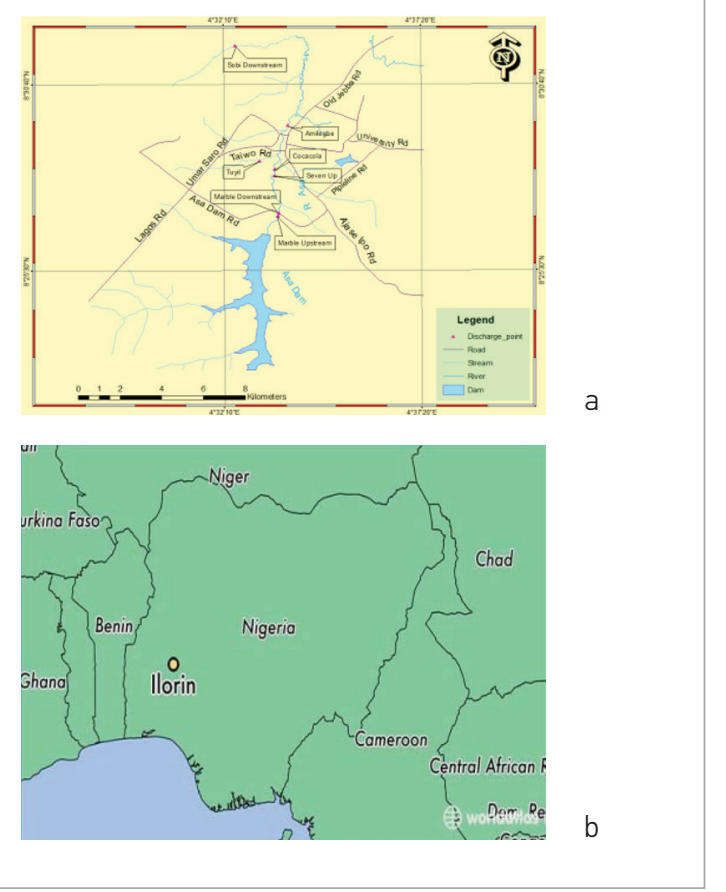

\section{Sample Collection}

Six sampling locations (Table 1) which spread across Asa River at llorin were carefully selected and were marked using Global Positioning System model German GPS 60. These locations cover the areas from which some of the pollutions such as human and animal wastes, agricultural activities as well as industrial discharges enter the river body.

The locations selected were divided into upstream section; points of industrial discharges; municipal and agricultural waste disposal point and downstream section of the river. The water samples were taken during months of June, July and August of 2014 (Rainy season) while November and December of 2014 as well as Month of January of 2015 for dry season. Six samples were collected at each point in a six different locations with three replicates in each location for a period of six months on monthly basis using grab methods with $750 \mathrm{ml}$ plastic bottles that has been rinsed first with $\mathrm{HCl}$ to avoid contamination and pollutants adsorption and then with distilled water (APHA, 1998).

\section{Water Quality Tests}

\section{Physical Parameters}

Physical parameters of water samples such as $\mathrm{pH}$, conductivity, total dissolved solids, hardness were determined using EDTA titration while electrical conductivity was done using conductivity meter, chloride using Mohr method of titration, nitrate using colorimetric

\begin{tabular}{|c|c|c|c|}
\hline \multirow{2}{*}{$\begin{array}{l}\text { Sampling } \\
\text { Points }\end{array}$} & \multirow{2}{*}{ Name } & \multicolumn{2}{|c|}{ Geographic Coordinate } \\
\hline & & Latitude & Longitude \\
\hline 1 & 2 & 3 & 4 \\
\hline A & Upstream Sampling Location (Asa Dam Road) & N8²6.9953' & $E 4^{\circ} 33.5398^{\prime}$ \\
\hline B & Marble factory discharge point (Onikolobo Street) & N8²7.192' & $E 4^{\circ} 33.5777^{\prime}$ \\
\hline C & Coca cola factory discharge point (Coca cola) & N8²8.1402' & $E 4^{\circ} 33.4948^{\prime}$ \\
\hline $\mathrm{D}$ & Tuyil Pharmaceutical Industry discharge point (Unity) & $8^{\circ} 28.6952$ & $E 4^{\circ} 33.4863^{\prime}$ \\
\hline$E$ & Amilegbe Sampling Location & N8²9.8623' & $E 4^{\circ} 334.711^{\prime}$ \\
\hline $\mathrm{F}$ & Sobi Sampling Location & N8॰38.9080’ & $E 4^{\circ} 43.960^{\prime}$ \\
\hline
\end{tabular}

\section{Table 1}

Detailed Description of Sampling Locations along Asa River 
method and sulphate using turbidimetric method. Total dissolved solids, total solids, total suspended solids dissolved solids were determined using the gravimetric method All the analyses were carried out in the laboratory of Department of Chemistry, University of Ilorin, llorin using standard procedures recommended by the American Public Health Association (APHA, 1998).

\section{Chemical Properties}

Chemical properties such as total hardness was determined using the complexometric titration (EDTA), dissolved oxygen by the Winkler method, biochemical oxygen demand and chemical oxygen demand using standard procedure (APHA, 1998) the chloride ion was determined the Mohr method, nitrate by the colorimetric method and phosphate using the spectophotometric method of determination (APHA, 1998)

\section{Artificial Neural Network Development}

Two different ANN models were developed in this study. These models were used to determine the significant parameters affected by water quality index (Biochemical Oxygen Demand and Dissolved Oxygen). For this matter, the first step of model prediction was conducted to reduce the insignificant parameters by using statistical analysis (IBM SPSS Statistics 21) which includes the leave one out method based on the correlation between each parameter with water quality index in order to recognize which parameters contribute most into the water quality index of Asa River.

\section{Choice of Inputs and Output Variable and Data Processing}

The monthly data of seventeen (17) water quality parameters that were measured over a period of six months at all the six sampling locations were selected for this analysis. The Dissolved oxygen (DO) and Biochemical Oxygen Demand (BOD) were used as water quality assessment index i.e. dependent variable or output in each of the ANN model development for their computation. The inputs or independent variable factors were Chemical Oxygen Demand (COD), pH, Electrical conductivity (EC), Total Dissolved Solid (TDS), Total Suspended Solid
(TSS), Temperature $\left({ }^{\circ} \mathrm{C}\right)$, Total Hardness, Calcium (Ca), Total Acidity, Turbidity, Nitrate $\left(\mathrm{NO}_{3}\right)$, Phosphate $\left(\mathrm{PO}_{4}\right)$, Chloride $\left(\mathrm{Cl}^{-}\right)$, Sulphate $\left(\mathrm{SO}_{4}\right)$ and Magnesium $(\mathrm{Mg})$.

The available data was randomly divided into two sets, one for the training and the other for validation each network, $86 \%$ were used for the network training while the remaining $14 \%$ were used to validate the network in each of the models. Six hundred and thirty (630) data sets were trained as input and the range of data used for the input and output variable were summarized in Tables 2 to 13.

The representation of training and validating data sets with respect to each other was carried out using statistical analysis (IBM SPSS Statistics 21) so as to enable general representation of a single population.

\section{Selection of Model Architecture}

The three layer feed-forward model with back-propagation multi-layer perceptron (MLP) type of neural network was used. In this architecture, each node at input and hidden layers received input values, processed it and passed it to the next layer. This was based on the supervised procedure i.e. the network constructs a model based on examples of the data with known outputs. The choice of this type of neural network is as a result of its efficient and reliable training algorithm technique (Fig 2) that helps in the distribution of the error in order to arrive at a best fit or minimum error and it is the most popular and widely used type of Artificial Neural Network for a wide variety of task by researchers based on literature.

For the Neural Network development, a set of inputs and output were selected from the training set and the network calculated the output based on the inputs supplied. The training set was used to train the network whereas the validation set was used to monitor or test the network performance at regular stages of the training. During the training, weights of input and hidden layer nodes were adjusted by checking the training and testing stage performances of neural network as automated in ALYUDA forecaster.

The output produced was then subtracted from the actual to find the output-layer error. The error was back-propagated through the network and the weights were suitably adjusted. This process continued until a 
pre specified error tolerance was reached as shown using the flow chart of Fig 2. The mean square error over the training samples is the typical objective function to be minimized and it uses the back propagation of the error gradient. Alyuda Forecaster XL software was employed for the proper training and validating of the network.

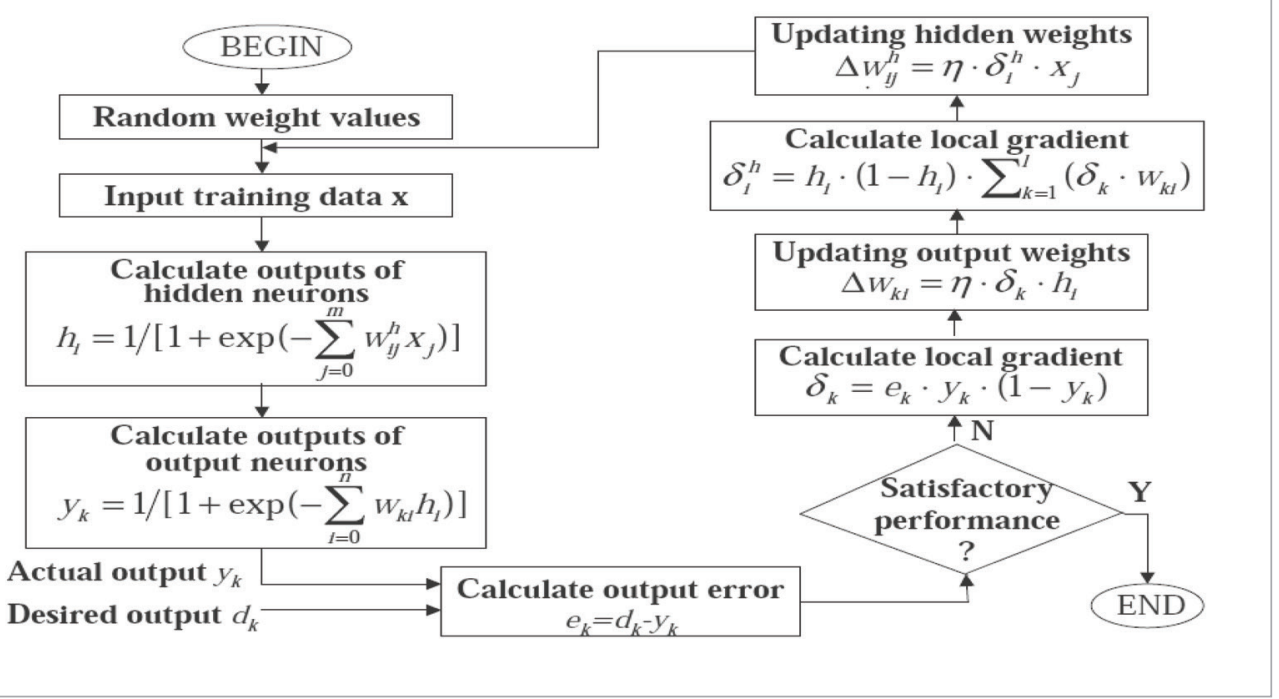

Fig. 2

Flow Chart for the Training of the Network

\section{Model Performance Criteria}

A multi-criteria approach was used for evaluating the performance of the models developed. Three statistical error and goodness-of-fit measures, including absolute error ( $A E)$, mean squared error (MSE) and $R$ value were used in order to evaluate the effectiveness of each network and its ability to make precise prediction. Scatter plots and deviation graphs were used for visual comparison of the observed and predicted values. The $\mathrm{R}$ value and RMS Error indicate how close one data series is to another. The data series were the target (actual) output values generated by the model. $R$ values range from -1.0 to +1.0. A larger (absolute value) $R$ value indicates a higher correlation.

\section{Sensitivity Analysis}

Sensitivity analysis was carried out to evaluate the relative importance of each of the fifteen input variables in predicting water quality index. Stepwise regression analysis was used which employed leave one out approach in order to identify the most significant input-output relationship. However, the sensitivity is defined as the
RMSE value indicates the performance of the network if the variable under consideration is removed from the analysis. Thus, disappearance of more important variables results in higher RMSE values indicating that the network is affected to greater extent when these variables were not included (Lee et al., 2003).

\section{Results and Discussion}

\section{Description of sampling locations}

The three layer feed-forward model with back-propagation multi-layer perceptron (MLP) type of neural network with the architecture of 15-9-1 for BOD and 15-13-1 for OD as input, hidden and output units respectively was used for the duration of the study (six months June-August 2014-peak of Rainy Season, November 2014 to January 2015-peak of the Dry Season). The data was collected from Asa River, Ilorin, Kwara State. The detailed description of sampling locations along Asa River is as shown in Fig 1 (a) and Table 1. Each location includes both point and non point sources 
types of pollution. In llorin, peak rainfall periods normally fall between June and September while the peak dry seasons fall between November and March. The selection of months of June to December, 2014 and January, 2015 as peak periods of raining and dry season was to capture some activities like flood and refuse dumping into river that normally resulted into river water pollution.

\section{Results of physical and chemical tests}

Tables 2 to 13 indicate the summary of the physical and chemical parameters used in this study. Table 2 shows that for $\mathrm{pH}$, the lowest value of 6.75 and the highest value of 6.94 were recorded during the month of June, 2014.

\section{Table 2}

Mean Values of Physical Parameters of Water Samples for June, 2014

\begin{tabular}{c|c|c|c|c|c|c}
\hline Sampling Points & $\mathrm{pH}$ & Turbidity (NTU) & TDS $(\mathrm{mg} / \mathrm{L})$ & TSS $(\mathrm{mg} / \mathrm{L})$ & Temp $\left({ }^{\circ} \mathrm{C}\right)$ & $\mathrm{EC}(\mu \mathrm{S} / \mathrm{cm})$ \\
\hline 1 & 2 & 3 & 4 & 5 & 6 & 7 \\
\hline A & 6.75 & 12.65 & 230 & 226.45 & 22.88 & 115.10 \\
\hline B & 6.94 & 12.58 & 210 & 223.50 & 22.56 & 124.00 \\
\hline C & 6.93 & 12.85 & 240 & 228.90 & 23.13 & 171.00 \\
\hline D & 6.85 & 13.54 & 480 & 262.11 & 26.69 & 172.00 \\
\hline E & 6.80 & 13.28 & 380 & 248.10 & 25.19 & 120.00 \\
\hline F & 6.90 & 12.90 & 310 & 233.60 & 23.67 & 123.10 \\
\hline
\end{tabular}

\section{Table 3}

Mean Values of the Chemical Parameters of Water Samples for June, 2014

\begin{tabular}{c|c|c|c|c|c|c|c|c|c|c|c}
\hline $\begin{array}{c}\text { Sampling } \\
\text { Points }\end{array}$ & $\begin{array}{c}\mathrm{DO} \\
(\mathrm{mg} / \mathrm{L})\end{array}$ & $\begin{array}{c}\mathrm{BOD} \\
(\mathrm{mg} / \mathrm{L})\end{array}$ & $\begin{array}{c}\mathrm{COD} \\
(\mathrm{mg} / \mathrm{L})\end{array}$ & $\begin{array}{c}\text { Hardness } \\
(\mathrm{mg} / \mathrm{L})\end{array}$ & $\begin{array}{c}\text { Chloride } \\
(\mathrm{mg} / \mathrm{L})\end{array}$ & $\begin{array}{c}\text { Sulphate } \\
(\mathrm{mg} / \mathrm{L})\end{array}$ & $\begin{array}{c}\text { Phosphate } \\
(\mathrm{mg} / \mathrm{L})\end{array}$ & $\begin{array}{c}\text { Calcium } \\
(\mathrm{mg} / \mathrm{L})\end{array}$ & $\begin{array}{c}\text { Magnesium } \\
(\mathrm{mg} / \mathrm{L})\end{array}$ & $\begin{array}{c}\text { Acidity } \\
(\mathrm{mg} / \mathrm{L})\end{array}$ & $\begin{array}{c}\text { Nitrate } \\
(\mathrm{mg} / \mathrm{L})\end{array}$ \\
\hline 1 & 2 & 3 & 4 & 5 & 6 & 7 & 8 & 9 & 10 & 11 \\
\hline $\mathrm{A}$ & 10.86 & 3.24 & 24 & 30.55 & 12.80 & 30.20 & 1.80 & 19.77 & 10.78 & 11.80 & 2.60 \\
\hline $\mathrm{B}$ & 12.28 & 3.53 & 31 & 45.92 & 18.60 & 35.60 & 1.90 & 28.40 & 17.52 & 10.38 & 3.20 \\
\hline $\mathrm{C}$ & 19.24 & 4.02 & 19 & 50.08 & 15.20 & 28.60 & 1.60 & 27.92 & 22.16 & 10.45 & 2.80 \\
\hline $\mathrm{D}$ & 14.47 & 5.02 & 26 & 39.12 & 16.38 & 35.60 & 1.40 & 19.35 & 19.77 & 10.68 & 2.20 \\
\hline $\mathrm{E}$ & 18.57 & 5.46 & 22 & 32.59 & 10.86 & 29.20 & 1.90 & 22.13 & 10.46 & 10.75 & 4.10 \\
\hline $\mathrm{F}$ & 19.44 & 4.82 & 28 & 41.38 & 14.30 & 28.90 & 1.60 & 20.16 & 21.22 & 10.60 & 2.40 \\
\hline
\end{tabular}




\section{Table 4}

Mean Values of Physical Parameters of Water Samples for July, 2014

\begin{tabular}{c|c|c|c|c|c|c}
\hline Sampling Points & $\mathrm{pH}$ & Turbidity (NTU) & TDS $(\mathrm{mg} / \mathrm{L})$ & TSS $(\mathrm{mg} / \mathrm{L})$ & Temp $\left({ }^{\circ} \mathrm{C}\right)$ & $\mathrm{EC}(\mu \mathrm{S} / \mathrm{cm})$ \\
\hline 1 & 2 & 3 & 4 & 5 & 6 & 7 \\
\hline A & 6.75 & 12.63 & 230 & 226.4 & 22.87 & 115.20 \\
\hline B & 6.95 & 12.56 & 210 & 223.0 & 22.51 & 125.00 \\
\hline C & 6.91 & 12.83 & 230 & 228.79 & 23.11 & 171.40 \\
\hline D & 6.88 & 13.50 & 480 & 262.12 & 26.69 & 174.00 \\
\hline E & 6.82 & 13.20 & 370 & 247.90 & 25.16 & 120.50 \\
\hline F & 6.90 & 12.92 & 320 & 233.80 & 23.70 & 123.20 \\
\hline
\end{tabular}

\section{Table 5}

Mean Values of the Chemical Parameters of Water Samples for July, 2014

\begin{tabular}{c|c|c|c|c|c|c|c|c|c|c|c}
\hline $\begin{array}{c}\text { Sampling } \\
\text { Points }\end{array}$ & $\begin{array}{c}\mathrm{DO} \\
(\mathrm{mg} / \mathrm{L})\end{array}$ & $\begin{array}{c}\mathrm{BOD} \\
(\mathrm{mg} / \mathrm{L})\end{array}$ & $\begin{array}{c}\mathrm{COD} \\
(\mathrm{mg} / \mathrm{L})\end{array}$ & $\begin{array}{c}\text { Hardness } \\
(\mathrm{mg} / \mathrm{L})\end{array}$ & $\begin{array}{c}\text { Chloride } \\
(\mathrm{mg} / \mathrm{L})\end{array}$ & $\begin{array}{c}\text { Sulphate } \\
(\mathrm{mg} / \mathrm{L})\end{array}$ & $\begin{array}{c}\text { Phosphate } \\
(\mathrm{mg} / \mathrm{L})\end{array}$ & $\begin{array}{c}\text { Calcium } \\
(\mathrm{mg} / \mathrm{L})\end{array}$ & $\begin{array}{c}\text { Magnesium } \\
(\mathrm{mg} / \mathrm{L})\end{array}$ & $\begin{array}{c}\text { Acidity } \\
(\mathrm{mg} / \mathrm{L})\end{array}$ & $\begin{array}{c}\text { Nitrate } \\
(\mathrm{mg} / \mathrm{L})\end{array}$ \\
\hline 1 & 2 & 3 & 4 & 5 & 6 & 7 & 8 & 9 & 10 & 11 & 12 \\
\hline A & 10.89 & 3.28 & 25 & 30.60 & 12.75 & 30.25 & 1.80 & 19.78 & 10.82 & 11.80 & 2.70 \\
\hline B & 12.26 & 3.53 & 30 & 45.90 & 18.80 & 35.80 & 1.80 & 28.37 & 17.53 & 10.40 & 3.00 \\
\hline C & 19.28 & 4.01 & 19 & 50.12 & 15.10 & 28.55 & 1.50 & 27.97 & 22.15 & 10.50 & 2.60 \\
\hline D & 14.40 & 5.00 & 28 & 39.10 & 16.40 & 35.80 & 1.50 & 19.40 & 19.70 & 10.62 & 2.60 \\
\hline E & 18.55 & 5.42 & 23 & 32.56 & 10.87 & 29.40 & 1.90 & 22.14 & 10.42 & 10.72 & 4.00 \\
\hline F & 19.40 & 4.80 & 28 & 41.42 & 14.20 & 28.95 & 1.60 & 20.22 & 21.20 & 10.62 & 2.30 \\
\hline
\end{tabular}

Table 6

Mean Values of the Physical Parameters of Water Samples for August, 2014

\begin{tabular}{c|c|c|c|c|c|c}
\hline Sampling Points & $\mathrm{pH}$ & Turbidity NTU & TDS $(\mathrm{mg} / \mathrm{L})$ & TSS $(\mathrm{mg} / \mathrm{L})$ & Temp $\left({ }^{\circ} \mathrm{C}\right)$ & EC $(\mu \mathrm{S} / \mathrm{cm})$ \\
\hline 1 & 2 & 3 & 4 & 5 & 6 & 7 \\
\hline A & 6.78 & 12.64 & 230 & 226.5 & 22.88 & 115.30 \\
\hline B & 6.94 & 12.54 & 200 & 223.2 & 23.11 & 125.00 \\
\hline C & 6.92 & 12.86 & 230 & 26.78 & 26.67 & 176.00 \\
\hline D & 6.86 & 13.50 & 470 & 262.00 & 25.18 & 120.40 \\
\hline E & 6.84 & 12.25 & 380 & 238.00 & 23.66 & 123.30 \\
\hline F & 6.91 & 12.91 & 310 & 233.50 & & 2 \\
\hline
\end{tabular}




\section{Table 7}

Mean Values of the Chemical Parameters of Water Samples for August, 2014

\begin{tabular}{c|c|c|c|c|c|c|c|c|c|c|c}
\hline $\begin{array}{c}\text { Sampling } \\
\text { Points }\end{array}$ & $\begin{array}{c}\mathrm{DO} \\
(\mathrm{mg} / \mathrm{L})\end{array}$ & $\begin{array}{c}\mathrm{BOD} \\
(\mathrm{mg} / \mathrm{L})\end{array}$ & $\begin{array}{c}\mathrm{COD} \\
(\mathrm{mg} / \mathrm{L})\end{array}$ & $\begin{array}{c}\text { Hardness } \\
(\mathrm{mg} / \mathrm{L})\end{array}$ & $\begin{array}{c}\text { Chloride } \\
(\mathrm{mg} / \mathrm{L})\end{array}$ & $\begin{array}{c}\text { Sulphate } \\
(\mathrm{mg} / \mathrm{L})\end{array}$ & $\begin{array}{c}\text { Phosphate } \\
(\mathrm{mg} / \mathrm{L})\end{array}$ & $\begin{array}{c}\text { Calcium } \\
(\mathrm{mg} / \mathrm{L})\end{array}$ & $\begin{array}{c}\text { Magnesium } \\
(\mathrm{mg} / \mathrm{L})\end{array}$ & $\begin{array}{c}\text { Acidity } \\
(\mathrm{mg} / \mathrm{L})\end{array}$ & $\begin{array}{c}\text { Nitrate } \\
(\mathrm{mg} / \mathrm{L})\end{array}$ \\
\hline 1 & 2 & 3 & 4 & 5 & 6 & 7 & 8 & 9 & 10 & 11 & 12 \\
\hline A & 10.82 & 3.26 & 24 & 30.58 & 12.78 & 30.28 & 1.80 & 19.74 & 10.84 & 11.78 & 2.70 \\
\hline B & 12.29 & 3.53 & 32 & 45.96 & 18.70 & 35.90 & 1.90 & 28.39 & 17.57 & 10.38 & 3.00 \\
\hline C & 19.22 & 4.00 & 20 & 50.14 & 15.15 & 28.62 & 1.60 & 27.99 & 22.15 & 10.44 & 2.50 \\
\hline D & 14.49 & 5.06 & 29 & 39.18 & 16.41 & 35.90 & 1.50 & 19.42 & 19.76 & 10.64 & 2.40 \\
\hline E & 18.61 & 5.44 & 22 & 32.55 & 10.90 & 29.50 & 1.80 & 22.11 & 10.44 & 10.70 & 4.20 \\
\hline F & 19.46 & 4.85 & 29 & 41.45 & 14.25 & 28.93 & 1.50 & 20.22 & 21.23 & 10.54 & 2.40 \\
\hline
\end{tabular}

\section{Table 8}

Mean Values of the Physical Parameters of Water Samples for November, 2014

\begin{tabular}{|c|c|c|c|c|c|c|}
\hline Sampling Points & $\mathrm{pH}$ & Turbidity NTU & TDS (mg/L) & TSS (mg/L) & Temp $\left({ }^{\circ} \mathrm{C}\right)$ & $\mathrm{EC}(\mu \mathrm{S} / \mathrm{cm})$ \\
\hline 1 & 2 & 3 & 4 & 5 & 6 & 7 \\
\hline$A$ & 6.85 & 12.40 & 211 & 200.40 & 20.25 & 110.60 \\
\hline B & 6.99 & 12.50 & 200 & 200.20 & 20.22 & 120.50 \\
\hline C & 6.95 & 12.70 & 201 & 200.04 & 20.21 & 168.90 \\
\hline $\mathrm{D}$ & 6.88 & 13.20 & 365 & 200.01 & 24.57 & 171.40 \\
\hline$E$ & 6.90 & 13.00 & 250 & 223.00 & 22.55 & 120.00 \\
\hline $\mathrm{F}$ & 6.94 & 12.60 & 230 & 211.18 & 21.35 & 120.80 \\
\hline
\end{tabular}

\section{Table 9}

Mean Values of the Chemical Parameters of Water Samples for November, 2014

\begin{tabular}{c|c|c|c|c|c|c|c|c|c|c|c}
\hline $\begin{array}{c}\text { Sampling } \\
\text { Points }\end{array}$ & $\begin{array}{c}\mathrm{DO} \\
(\mathrm{mg} / \mathrm{L})\end{array}$ & $\begin{array}{c}\mathrm{BOD} \\
(\mathrm{mg} / \mathrm{L})\end{array}$ & $\begin{array}{c}\mathrm{COD} \\
(\mathrm{mg} / \mathrm{L})\end{array}$ & $\begin{array}{c}\text { Hardness } \\
(\mathrm{mg} / \mathrm{L})\end{array}$ & $\begin{array}{c}\text { Chloride } \\
(\mathrm{mg} / \mathrm{L})\end{array}$ & $\begin{array}{c}\text { Sulphate } \\
(\mathrm{mg} / \mathrm{L})\end{array}$ & $\begin{array}{c}\text { Phosphate } \\
(\mathrm{mg} / \mathrm{L})\end{array}$ & $\begin{array}{c}\text { Calcium } \\
(\mathrm{mg} / \mathrm{L})\end{array}$ & $\begin{array}{c}\text { Magnesium } \\
(\mathrm{mg} / \mathrm{L})\end{array}$ & $\begin{array}{c}\text { Acidity } \\
(\mathrm{mg} / \mathrm{L})\end{array}$ & $\begin{array}{c}\text { Nitrate } \\
(\mathrm{mg} / \mathrm{L})\end{array}$ \\
\hline 1 & 2 & 3 & 4 & 5 & 6 & 7 & 8 & 9 & 10 & 11 & 12 \\
\hline A & 11.63 & 3.58 & 23 & 29.29 & 12.80 & 29.50 & 1.60 & 18.78 & 10.50 & 10.75 & 2.20 \\
\hline B & 19.42 & 4.02 & 30 & 44.48 & 17.80 & 32.40 & 1.80 & 27.70 & 16.68 & 10.54 & 3.00 \\
\hline C & 19.06 & 5.56 & 18 & 48.60 & 14.20 & 26.90 & 1.50 & 26.80 & 21.80 & 10.60 & 2.10 \\
\hline D & 15.45 & 6.02 & 24 & 37.75 & 16.12 & 25.80 & 1.30 & 18.65 & 19.10 & 10.69 & 2.05 \\
\hline E & 18.80 & 6.00 & 21 & 31.36 & 10.15 & 25.40 & 1.80 & 21.18 & 10.18 & 10.65 & 3.80 \\
\hline F & 19.61 & 5.69 & 27 & 40.35 & 13.35 & 23.55 & 1.60 & 19.85 & 20.40 & 10.62 & 2.10 \\
\hline
\end{tabular}




\section{Table 10}

Mean Values of the Physical Parameters of Water Samples for December, 2014

\begin{tabular}{c|c|c|c|c|c|c}
\hline Sampling Points & $\mathrm{pH}$ & Turbidity $(\mathrm{NTU})$ & TDS $(\mathrm{mg} / \mathrm{L})$ & TSS $(\mathrm{mg} / \mathrm{L})$ & Temp $\left({ }^{\circ} \mathrm{C}\right)$ & EC $(\mu \mathrm{S} / \mathrm{cm})$ \\
\hline 1 & 2 & 3 & 4 & 5 & 6 & 7 \\
\hline A & 6.86 & 12.45 & 210 & 200.40 & 20.25 & 110.80 \\
\hline B & 6.98 & 12.52 & 202 & 200.25 & 20.23 & 120.40 \\
\hline C & 6.98 & 12.75 & 200 & 200.80 & 20.21 & 168.30 \\
\hline D & 6.90 & 13.30 & 363 & 242.03 & 24.57 & 171.00 \\
\hline E & 6.92 & 13.10 & 258 & 223.15 & 22.57 & 120.00 \\
\hline F & 6.96 & 12.62 & 240 & 211.22 & 21.36 & 120.91 \\
\hline
\end{tabular}

\section{Table 11}

Mean Values of the Chemical Parameters of Water Samples for December, 2014

\begin{tabular}{c|c|c|c|c|c|c|c|c|c|c|c}
\hline $\begin{array}{c}\text { Sampling } \\
\text { Points }\end{array}$ & $\begin{array}{c}\mathrm{DO} \\
(\mathrm{mg} / \mathrm{L})\end{array}$ & $\begin{array}{c}\mathrm{BOD} \\
(\mathrm{mg} / \mathrm{L})\end{array}$ & $\begin{array}{c}\mathrm{COD} \\
(\mathrm{mg} / \mathrm{L})\end{array}$ & $\begin{array}{c}\text { Hardness } \\
(\mathrm{mg} / \mathrm{L})\end{array}$ & $\begin{array}{c}\text { Chloride } \\
(\mathrm{mg} / \mathrm{L})\end{array}$ & $\begin{array}{c}\text { Sulphate } \\
(\mathrm{mg} / \mathrm{L})\end{array}$ & $\begin{array}{c}\text { Phosphate } \\
(\mathrm{mg} / \mathrm{L})\end{array}$ & $\begin{array}{c}\text { Calcium } \\
(\mathrm{mg} / \mathrm{L})\end{array}$ & $\begin{array}{c}\text { Magnesium } \\
(\mathrm{mg} / \mathrm{L})\end{array}$ & $\begin{array}{c}\text { Acidity } \\
(\mathrm{mg} / \mathrm{L})\end{array}$ & $\begin{array}{c}\text { Nitrate } \\
(\mathrm{mg} / \mathrm{L})\end{array}$ \\
\hline 1 & 2 & 3 & 4 & 5 & 6 & 7 & 8 & 9 & 10 & 11 & 12 \\
\hline A & 11.66 & 3.59 & 24 & 29.25 & 12.70 & 29.55 & 1.70 & 18.80 & 10.45 & 10.70 & 2.22 \\
\hline B & 19.40 & 4.02 & 31 & 44.50 & 17.90 & 32.40 & 1.70 & 27.80 & 16.70 & 10.55 & 2.98 \\
\hline C & 19.08 & 5.61 & 18 & 48.53 & 14.18 & 26.92 & 1.40 & 26.85 & 21.68 & 10.55 & 2.12 \\
\hline D & 15.50 & 6.03 & 26 & 37.90 & 16.10 & 25.85 & 1.40 & 18.70 & 19.20 & 10.65 & 2.04 \\
\hline E & 18.76 & 6.03 & 22 & 31.40 & 10.10 & 25.40 & 1.80 & 21.20 & 10.20 & 10.63 & 3.82 \\
\hline F & 19.63 & 5.68 & 28 & 40.31 & 13.40 & 23.50 & 1.50 & 19.86 & 20.45 & 10.58 & 2.15 \\
\hline
\end{tabular}

\section{Table 12}

Mean Values of the Physical Parameters of Water Samples for January, 2015

\begin{tabular}{c|c|c|c|c|c|c}
\hline Sampling Points & $\mathrm{pH}$ & Turbidity $(\mathrm{NTU})$ & TDS $(\mathrm{mg} / \mathrm{L})$ & TSS $(\mathrm{mg} / \mathrm{L})$ & Temp $\left({ }^{\circ} \mathrm{C}\right)$ & $\mathrm{EC}(\mu \mathrm{S} / \mathrm{cm})$ \\
\hline 1 & 2 & 3 & 4 & 5 & 6 & 7 \\
\hline A & 6.85 & 12.40 & 209 & 200.45 & 20.25 & 110.70 \\
\hline B & 6.98 & 12.50 & 201 & 200.30 & 20.23 & 120.40 \\
\hline C & 6.97 & 12.75 & 206 & 242.00 & 24.56 & 171.00 \\
\hline D & 6.90 & 13.10 & 360 & 223.18 & 22.57 & 120.00 \\
\hline E & 6.91 & 13.10 & 255 & 211.25 & 21.36 & 120.90 \\
\hline F & 6.95 & 12.64 & 235 & &
\end{tabular}




\section{Table 13}

Mean Values of the Chemical Parameters of Water Samples for January, 2015

\begin{tabular}{c|c|c|c|c|c|c|c|c|c|c|c}
\hline $\begin{array}{c}\text { Sampling } \\
\text { Points }\end{array}$ & $\begin{array}{c}\mathrm{DO} \\
(\mathrm{mg} / \mathrm{L})\end{array}$ & $\begin{array}{c}\mathrm{BOD} \\
(\mathrm{mg} / \mathrm{L})\end{array}$ & $\begin{array}{c}\mathrm{COD} \\
(\mathrm{mg} / \mathrm{L})\end{array}$ & $\begin{array}{c}\text { Hardness } \\
(\mathrm{mg} / \mathrm{L})\end{array}$ & $\begin{array}{c}\text { Chloride } \\
(\mathrm{mg} / \mathrm{L})\end{array}$ & $\begin{array}{c}\text { Sulphate } \\
(\mathrm{mg} / \mathrm{L})\end{array}$ & $\begin{array}{c}\text { Phosphate } \\
(\mathrm{mg} / \mathrm{L})\end{array}$ & $\begin{array}{c}\text { Calcium } \\
(\mathrm{mg} / \mathrm{L})\end{array}$ & $\begin{array}{c}\text { Magnesium } \\
(\mathrm{mg} / \mathrm{L})\end{array}$ & $\begin{array}{c}\text { Acidity } \\
(\mathrm{mg} / \mathrm{L})\end{array}$ & $\begin{array}{c}\text { Nitrate } \\
(\mathrm{mg} / \mathrm{L})\end{array}$ \\
\hline 1 & 2 & 3 & 4 & 5 & 6 & 7 & 8 & 9 & 10 & 11 \\
\hline A & 11.69 & 3.57 & 2.40 & 29.28 & 12.60 & 29.65 & 1.70 & 18.81 & 10.47 & 10.75 & 2.20 \\
\hline B & 19.45 & 4.03 & 3.10 & 44.50 & 17.80 & 32.60 & 1.80 & 27.80 & 16.70 & 10.55 & 2.98 \\
\hline C & 19.09 & 5.60 & 1.90 & 48.58 & 14.16 & 26.96 & 1.50 & 26.86 & 21.72 & 10.56 & 2.14 \\
\hline D & 15.48 & 6.05 & 2.50 & 37.83 & 16.10 & 25.75 & 1.40 & 18.68 & 19.15 & 10.65 & 2.05 \\
\hline E & 18.79 & 6.05 & 2.10 & 31.42 & 10.10 & 25.45 & 1.80 & 21.22 & 10.20 & 10.64 & 3.85 \\
\hline F & 19.64 & 5.67 & 2.70 & 40.36 & 13.40 & 23.60 & 1.50 & 19.88 & 20.48 & 10.60 & 2.15 \\
\hline
\end{tabular}

The range of the $\mathrm{pH}$ value of the river recorded falls between 6.75 and 6.99. This shows that water quality which was within the acceptable limits (NIS, 2007; WHO, 2011). The low value of $\mathrm{pH}$ (6.75) was recorded during the month of June at sampling point A (upstream) while slightly high values were recorded at sampling points $B, C, D, E$ and $F$ which can be attributed to the effluents from the industries and runoff from agricultural sites. The high $\mathrm{pH}$ values recorded in the dry season can be attributed to decrease in volume of water while the low values may be connected to the shorter day length and decrease in photosynthetic activity (Salve and Hiware, 2006). For turbidity, the lowest value of 12.25 NTU (Table 6) and highest value of 13.54 NTU (Table 2) were recorded. For total dissolved solids, the lowest value of $0.21 \mathrm{mg} / \mathrm{l}$ and highest value of $0.48 \mathrm{mg} / \mathrm{l}$ were recorded. For total suspended solids, the lowest value of $200.04 \mathrm{mg} / \mathrm{L}$ and highest value of $262.12 \mathrm{mg} / \mathrm{L}$ were recorded. For temperature, the lowest value of $22.51^{\circ} \mathrm{C}$ and highest value of $29.55^{\circ} \mathrm{C}$ were recorded. For electrical conductivity, the lowest value of $110.6 \mu \mathrm{S} / \mathrm{cm}$ and highest value of $176.00 \mu \mathrm{S} / \mathrm{cm}$ were recorded. Table 3 , shows that for DO, the lowest value of $10.82 \mathrm{mg} / \mathrm{L}$ and the highest value of $19.64 \mathrm{mg} / \mathrm{L}$ were recorded during the month of June, 2014.

For the biochemical oxygen demand, the lowest value of $3.24 \mathrm{mg} / \mathrm{L}$ and highest value of $6.05 \mathrm{mg} / \mathrm{L}$ were recorded. For the chemical oxygen demand, the lowest value of $18.00 \mathrm{mg} / \mathrm{L}$ and highest value of $32.00 \mathrm{mg} / \mathrm{L}$ were recorded. For the acidity, the maximum and minimum average values recorded were $10.80 \mathrm{mg} / \mathrm{L}$ and $10.38 \mathrm{mg} / \mathrm{L}$ respectively with a mean value of $10.63 \mathrm{mg} / \mathrm{L}$. For the total hardness, the lowest value of $29.25 \mathrm{mg} / \mathrm{L}$ and highest value of $50.14 \mathrm{mg} / \mathrm{L}$ were recorded. For the chloride, the lowest value of $10.10 \mathrm{mg} / \mathrm{L}$ and highest value of $18.80 \mathrm{mg} / \mathrm{L}$ were recorded. For the sulphate, the lowest value of $23.50 \mathrm{mg} / \mathrm{L}$ and highest value of $35.9 \mathrm{mg} / \mathrm{L}$ were recorded. For the phosphate, the lowest value of $1.3 \mathrm{mg} / \mathrm{L}$ and highest value of $1.9 \mathrm{mg} / \mathrm{L}$ were recorded. For the calcium, the lowest value of $18.65 \mathrm{mg} / \mathrm{L}$ and highest value of $28.40 \mathrm{mg} / \mathrm{L}$ were recorded. For the magnesium, the lowest value of $10.18 \mathrm{mg} / \mathrm{L}$ and highest value of $23.73 \mathrm{mg} / \mathrm{L}$ were recorded.

\section{Statistical Correlation of BOD and DO with Respective Inputted Parameters}

The statistical correlation of DO and BOD with their respective inputted parameters were calculated using IBM SPSS Statistics 21 for analyzing and examining the relation among the parameters so as to bring out the relative susceptibility of each parameter (Table 14).

For Dissolved oxygen (DO), pH (0.572), total hardness $(0.435)$ and magnesium (0.415) had highest correlation at 0.01 level of significant while acidity (0.297), phosphate (0.201) and chloride (0.161) had least correlation with dissolved oxygen (DO) in that order. For Biochemical oxygen demand (BOD), sulphate (0.771), turbidity 
(0.579) temperature (0.505) at 0.01 level of significant and electrical conductivity (0.353) at 0.05 level of significant had highest correlation while calcium (0.300), chemical oxygen demand (0.036) and hardness (0.097) had least correlation with biochemical oxygen demand (BOD) in that order.

Table 14

Descriptive Statistics of the Parameters

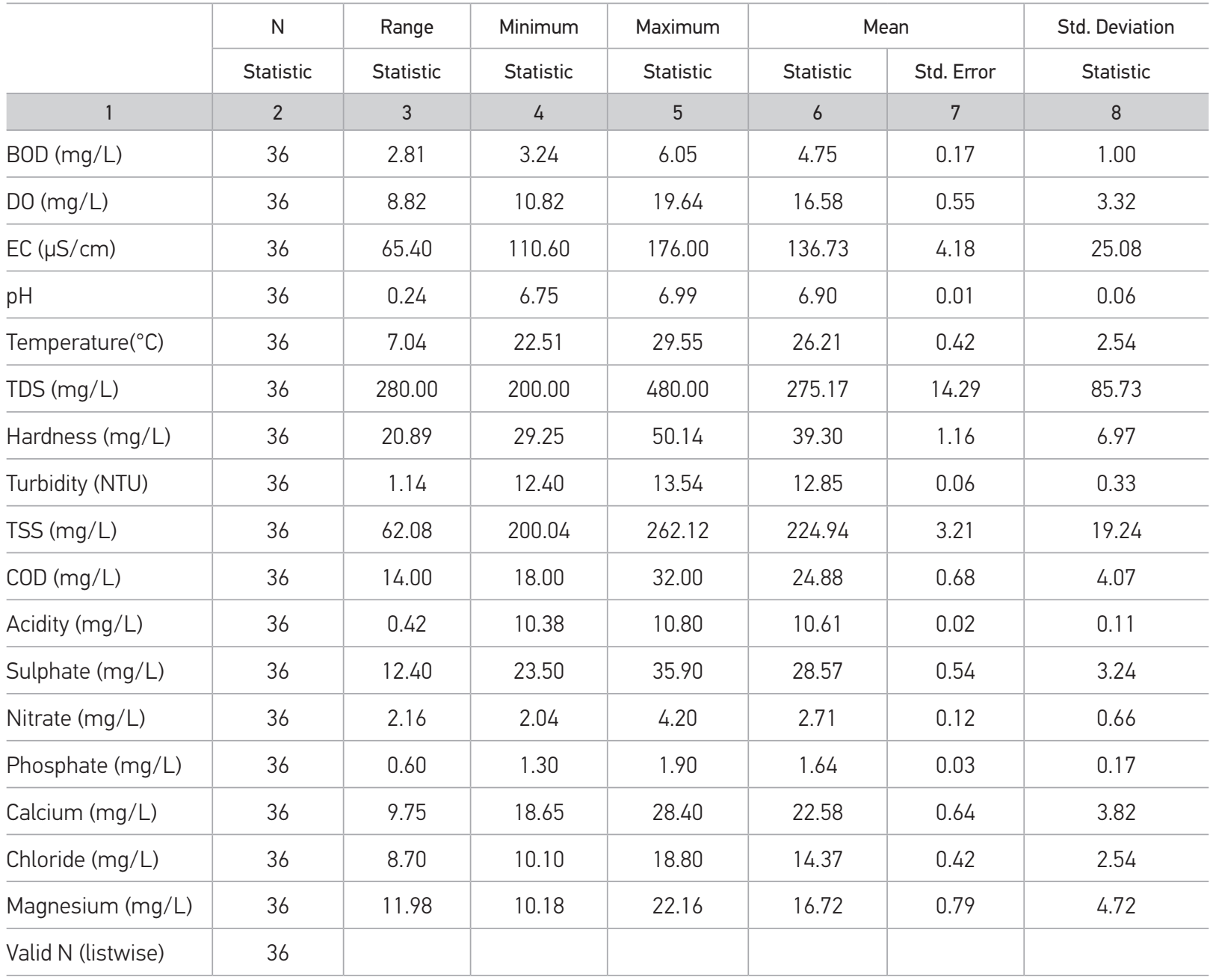

\section{Development of Artificial Neural Network models}

The development of Artificial Neural Network models for BOD and DO provided best fits models for all the training and validation sets used with the architecture of 15-9-1 for BOD and 15-13-1 for OD as input, hidden and output units respectively.

Figs 3 and 4 showed the training error graphs of BOD and $\mathrm{DO}$ respectively.
For BOD, training process went through 5022 iterations and during which the best training was achieved at iterations 1428 with Average error (AE) of 0.44 and Mean square error (MSE) of 2.85 while DO training process went through 5100 iterations and best training was achieved at iterations 1957 with Average error (AE) of 3.58 and Mean square error (MSE) of 89.86 . 
Fig 3

Measured and

Predicted BOD

against Samplings

of Asa River Water

Pollution (Model 1)

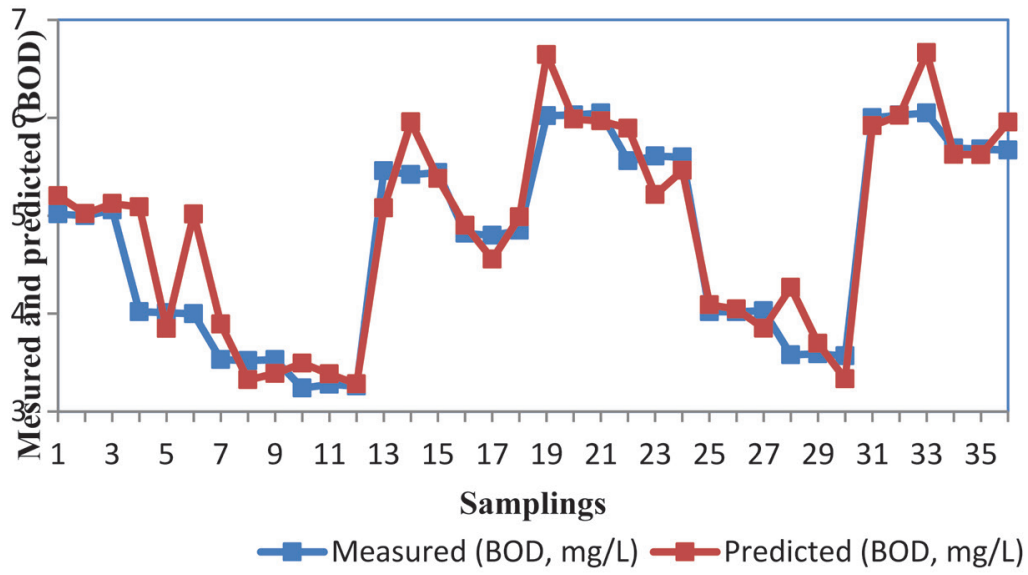

Fig 4

Measured and

Predicted DO

against Samplings

of Asa River Water

Pollution (Model 2)

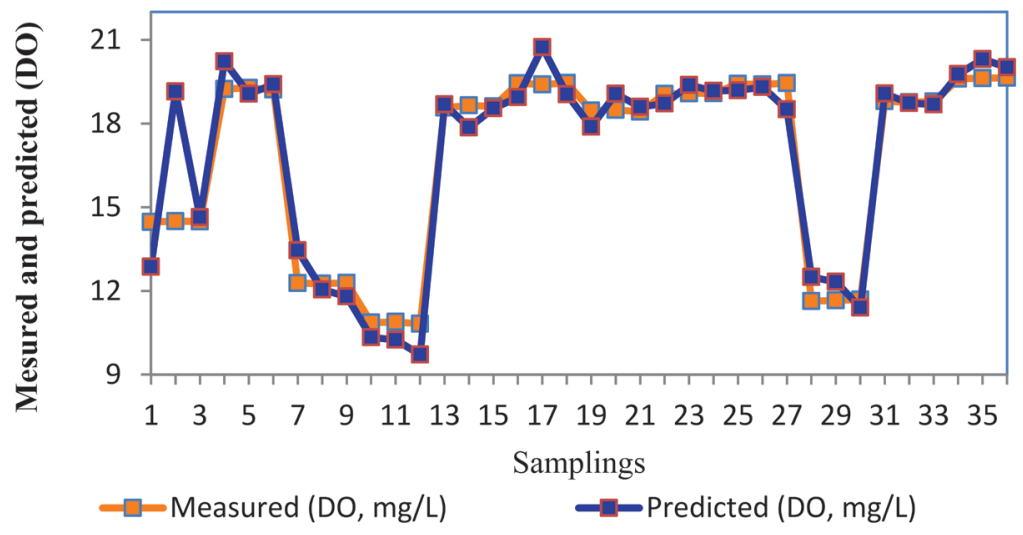

\section{Model Validation}

Figs 5 and 6 show the computed values of BOD and DO in training and validation sets respectively.

The correlation and R-Squared values for the training and validation of BOD and DO were $0.9525,0.9556$ and 0.8911 and 0.9042 respectively as shown in Table 14 for BOD and Table 15 for DO.

Closely followed patterns of variation by the actual and model computed BOD and DO values, AE and MSE values as shown in Tables 15-16 respectively suggest a good-fit of the selected BOD and DO models to the data sets respectively.
Fig 7 and 8 shows the relationship between the measured BOD and DO and their corresponding Artificial Neural Network predictions.

The figures demonstrate that reasonable approximations were made by the neural network models across the spectrum of the measured BOD and DO values. The overall agreement between the actual and predicted $B O D$ and $D O$ values was very satisfactory. 
Fig 5

Deviation of Error for Model 1 (BOD)

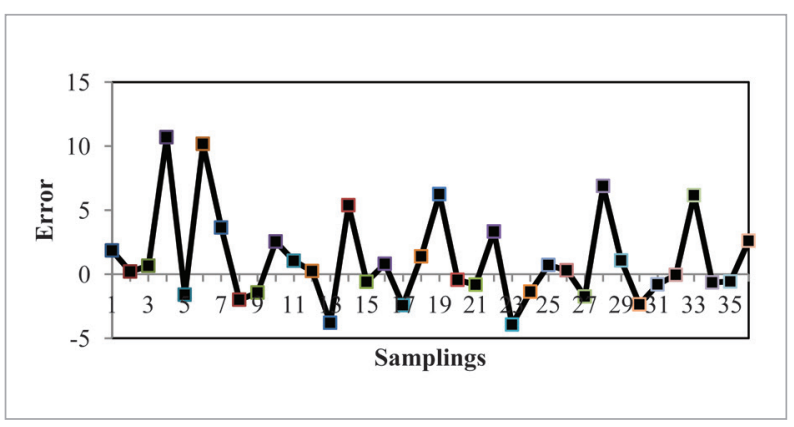

Fig 6

Deviation of Error for Model 2 (DO)

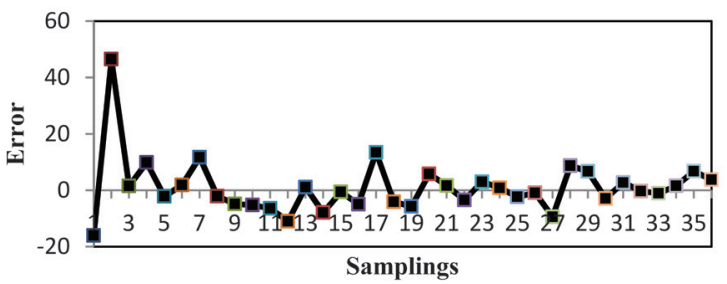

\begin{tabular}{l|c|c}
\hline \multicolumn{1}{c|}{1} & Training set & Validation set \\
\hline Number of rows & 2 & 3 \\
\hline Average AE & 30 & 6 \\
\hline Average MSE & 2.29 & 3.13 \\
\hline Tolerance type & 10.34 & 22.79 \\
\hline Tolerance & Relative & Relative \\
\hline$\%$ of Good forecast & $10 \%$ & $30 \%$ \\
\hline$\%$ of Bad forecast & $26(86 \%)$ & $6(100 \%)$ \\
\hline
\end{tabular}

Table 15

Performance

Evaluation of Model 1 (BOD)

R Squared: 0.8911, Correlation: 0.9525

\begin{tabular}{l|c|c}
\hline \multicolumn{1}{c|}{1} & Training set & Validation set \\
\hline Number of rows & 2 & 3 \\
\hline Average AE & 30 & 6 \\
\hline Average MSE & 4.65 & 13.00 \\
\hline Tolerance type & 36.86 & 379.08 \\
\hline Tolerance & Relative & Relative \\
\hline \% of Good forecast & $10 \%$ & $30 \%$ \\
\hline$\%$ of Bad forecast & $28(94 \%)$ & $5(86 \%)$ \\
\hline
\end{tabular}

Table 16

Performance Evaluation of Model 2 (DO)

R Squared: 0.9042, Correlation: 0.9556 


\section{Fig 7}

Artificial Neural Network Model 1 Validation (BOD)

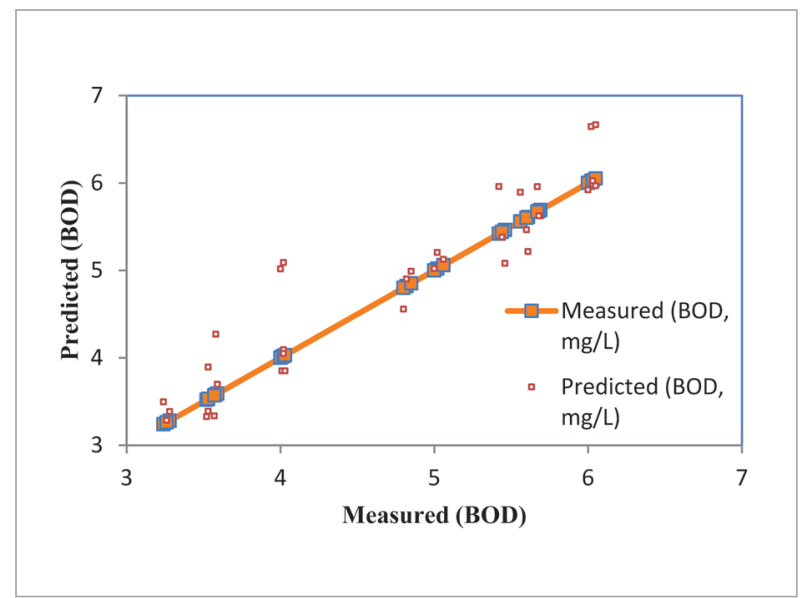

\section{Sensitivity Analysis of the models}

Figs 9 and 10 showed the sensitivity of different parameters in predicting neural networks for BOD and DO of Asa River respectively.

For BOD model, turbidity (21.113\%), total suspended solids (15.748\%) and magnesium (12.390\%) showed highest level of sensitivity in that order while phosphate $(1.0811 \%)$, chloride (1.221\%) and nitrate (1.439\%)

\section{Fig 9}

Sensitivity analysis results of BOD model

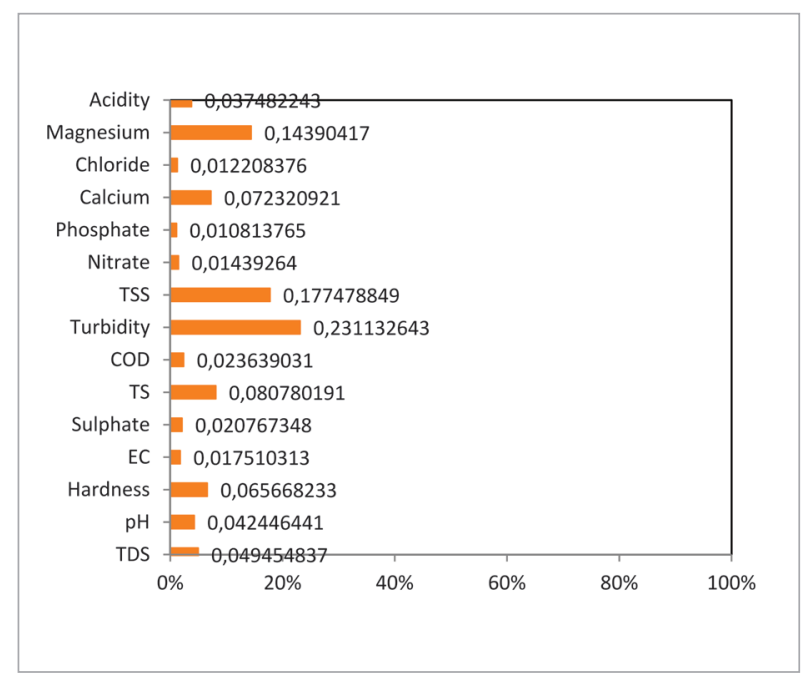

Fig 8

Artificial Neural Network Model 2 Validation (DO)

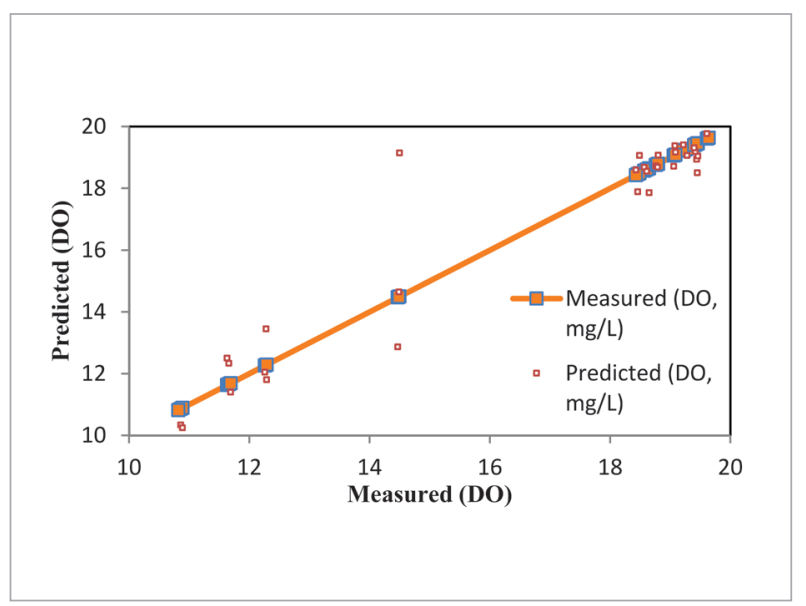

showed least level of sensitivity in that order. Hardness (15.641\%), temperature (14.013\%) and sulphate (10.012\%) showed high level of sensitivity in DO model while acidity (2.120\%), magnesium (2.536\%) and total suspended solids $(2.538 \%)$ in that order showed least sensitivity to DO model.

Fig 10

Sensitivity analysis results of DO model

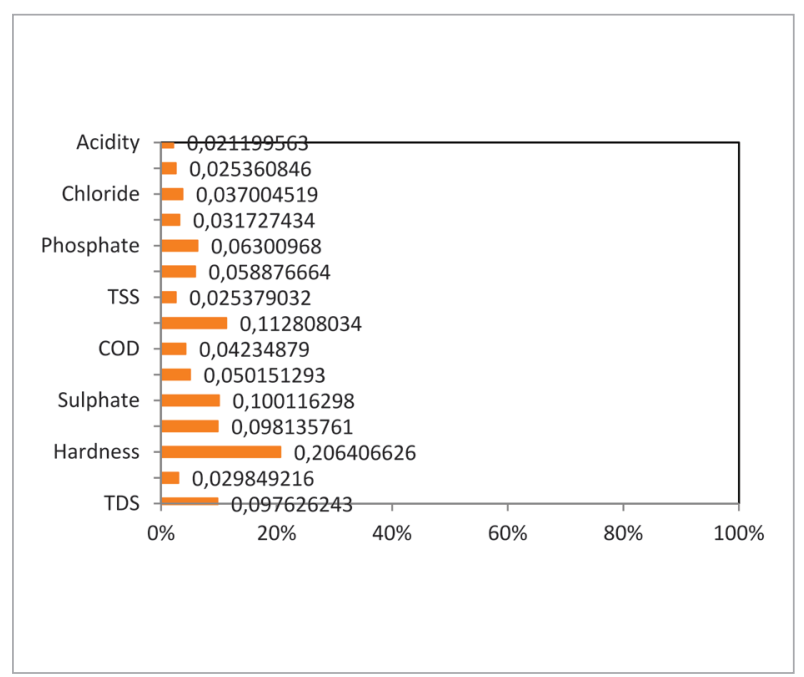




\section{Conclusions}

The study shows that predicted and the actual BOD and DO correlated very well. The correlation coefficient values between the predicted values and actual data for biochemical oxygen demand (BOD) and dissolved oxygen (DO) were 0.9525 and 0.9556 respectively, which are satisfactorily in common model applications. These results indicate that the neural network model is able to recognize the pattern of the water quality parameters to provide good predictions of the monthly variations of water quality data (BOD and DO) of the Asa River in Ilorin. This study therefore shows that the optimal networks are capable of capturing long term trends observed for the tedious water quality variables (BOD and DO), both in time and space (spatio-temporal). Therefore, Artificial Neural Network can be employed as an effective tool for the computation of river water quality and could also be used in other areas to improve the understanding of river pollution trends.

\section{References}

Abdulkadir, T. S., Sule, B. F. and Salami, A. W. 2012. Application of Artificial Neural Network Model to the Management of Hydropower Reservoirs along River Niger, Nigeria. Annals of Faculty Engineering, Hunedoara-International Journal of Engineering, Tome X-FASCICULE 1(ISSN 1584-2673), 419-424.

Adekunle A. S. and Eniola I. T. K. 2008. Industrial effluents on quality of segment of Asa River within an industrial estate in Ilorin, Nigeria. New York Sci. J. 1, 17-21.

Agrawal, A., Pandey, S. R. and Sharma, B. 2010. Water pollution with special reference to pesticide contamination in India. Journal of Water Resources and Protection, 2, 432-448. https://doi.org/10.4236/jwarp.2010.25050

American Public Health Association APHA, 1998. Standard Methods for the Examination of Water and Wastewater, 20th edition. Washington D.C.

Andy P. D., Peter, L. M., Goethals, W. G. and Niels, D. P. (2004). Optimization of Artificial Neural Network Model Design for Prediction of Macro-invertebrates in the Zwalm River Basin, Ecological Modeling, 174, 161-173. https://doi.org/10.1016/j. ecolmodel.2004.01.003

Eletta O. A., Adekola F. A. and Aderanti M. A. 2005. Assessment of Asa River: Impact of waste discharge from soft drink plant into Asa River, Ilorin. Nigerian J. Appl. Sci. Environ. Mgt., 9, 187-190.

Ibrahim, K. O., Okunlola, I. A. and Abdurrahman, A. 2013. Trace metal indices in the characterization of hydrogeochemical condition of surface water along Asa River, Ilorin, Kwara State, Nigeria. International Journal of Geology, Earth and Environmental Sciences, 3, 1, 29-35.
Jensen, B. A. 1994. Expert systems - neural networks, Instrument Engineers' Handbook, 3rd ed. Radnor, Pennsylvania, Chilton, 48-54.

Karim, S. 2009. Rainfall-Runoff Prediction Based on Artificial Neural Network (A Case Study: Jarahi Watershed), AmericanEurasian J. Agric.and Environ. Sci., 5, 6, 856-865.

Lee, J. H. W.; Huang, Y.; Dickman, M. and Jayawardena, A. W. 2003. Neural network modelling of coastal algal blooms. Ecological Modelling, 159, 179-201. https://doi.org/10.1016/ S0304-3800(02)00281-8

Nigerian Industrial Standard (NIS) 2007. Nigerian Standard for Drinking Water Quality. NIS554:2007, ICS 13.060.20, Approved by Standard Organization of Nigeria (SON) Governing Council, Pp. 14-18.

Ogundiran, M. A. and Fawole, 0. 0. 2014. Assessment of the Impacts of Industrial Effluent Discharges on the Water Quality of Asa River, Ilorin, Nigeria. Journal of Environmental Science, Toxicology and Food Technology, 8, 7, 80-98.

Ogunlela A. O. and Adelodun, B. 2014. Kinematic flood routing of Asa River, Ilorin, Nigeria. International Journal of Engineering and Technical Research, 2, 3, 13-17.

Waziri, M. and Ogugbuaja, V. O. 2010. Interrelationships between physicochemical water pollution indicators: A case study of River Yobe-Nigeria; Am. J. Sci. Ind. Res., 2010, 1, 1, $76-80$.

World Health Organization (WHO) 2011. Guidelines for Drinking Water Quality: 4th Edition. http://www.who.int. 


\section{Biocheminio deguonies suvartojimo ir ištirpusio deguonies kiekio upèse modeliavimas naudojant dirbtinius neuroninius tinklus: Asos upès atvejo studija}

\section{Kamoru Akanni Adeniran, Bashir Adelodun, Matthew Ogunshina}

Žemès ūkio inžinerijos kateda, lorino universitetas, Nigerija

Upiu ir vandens kokybès vertinimas apima ¡vairiu kokybės rodikliu nustatymą naudojantis analitiniais metodais, kurie dažnai yra sudetingi ir reikalaujantys daug laiko. Šiame tyrime buvo naudojamas dirbtinio neuroninio tinklo (DNT) metodas, kurio pagalba buvo modeliuojami ryšiai tarp penkiolikos (15) vandens kokybės rodikliu tikslu prognozuoti kitus du (2) rodiklius ir taip sumažinti ilgu eksperimentiniu procedūru naštą. Vandens mėginiai buvo surinkti iš šešių (6) sutelktujų ir pasklidujuu taršos šaltinių Asos upejje (Ilorine), lietingo sezono piko metu (birželio-rugpjūčio mèn., 2014) ir sausojo sezono piko metu (lapkričio-sausio mèn, 2015). Fiziniai ir cheminiai jeities rodikliai naudojami modelyje buvo sekantys: rūgštingumas (pH), drumstumas, bendroji ištirpusių kietujų medžiagu koncentracija, temperatūra, elektros laidumas, ištirpusi deguonies koncentracija (IDK), biologinis deguonies suvartojimas (BDS), cheminis deguonies suvartojimas (ChDS), kietumas, chlorido, sulfato, fosfato, kalcio, magnio kiekiai bei nitratu koncentracija. BDS ir IDK buvo modelio išeities rodikliai. Triju sluoksnių tiesioginio sklidimo modelis su klaidos sklidimo atgal MLP (angl. multilayer perception) modeliavimu ir architektūra BDS -15-9-1, o IDK a- 15-13-1 davè optimalius rezultatus su 9 ir 13 neurony pasleptame sluoksnyje atitinkamai BDS ir IDK rodikliams. Modeliu veikimas buvo ivertintas statistiniais metodais, buvo apskaičiuojamos vidutine paklaida ir vidutinè kvadratinè paklaida. Atitinkamai, paskaičiuoti ir DNT modeliu koreliacijos koeficientai BOD ir IDK prognozavimui, kurie atitinkamai buvo 0,9525 ir 0,9556. Jautrio analize taip pat buvo atlikta siekiant nustatyti stipriausią jvesties ir išvesties rodikliu santykị. Galime daryti pagrindę išvadą, kad DNT metodas yra veikiantis ir patikimas BOD ir IDK rodikliu prognozavimui Asos upeje.

Raktiniai žodžiai: dirbtiniai neuroniniai tinklai, modeliavimas, upių ir vandens kokybè. 